\title{
Glucosamine suppresses interleukin-8 production and ICAM-1 expression by TNF-a-stimulated human colonic epithelial HT-29 cells
}

\author{
SHIN YOMOGIDA ${ }^{1}$, JIAN HUA $^{1}$, KOJI SAKAMOTO ${ }^{2}$ and ISAO NAGAOKA ${ }^{1}$ \\ ${ }^{1}$ Department of Host Defense and Biochemical Research, Juntendo University, School of Medicine, 2-1-1 Hongo, \\ Bunkyo-ku, Tokyo 113-8421; ${ }^{2}$ Koyo Chemical Co., Ltd., 3-11-15 Iidabashi, Chiyoda-ku, Tokyo 112-0072, Japan
}

Received February 5, 2008; Accepted March 29, 2008

DOI: 10.3892/ijmm_00000010

\begin{abstract}
Intestinal epithelial cells play an important role in the mucosal immune reaction in inflammatory bowel diseases via the production and expression of chemokines and adhesion molecules, such as interleukin-8 (IL-8) and intercellular adhesion molecule-1 (ICAM-1), which are involved in the neutrophil infiltration and tissue damage in the inflamed colon. Notably, glucosamine, a naturally-occurring amino monosaccharide, has been shown to exhibit an antiinflammatory action by inhibiting neutrophil functions. In the present study, to evaluate the anti-inflammatory action of glucosamine on intestinal epithelial cells, we examined the effects of glucosamine on the activation of a human colonic epithelial cell line HT-29. The results revealed that glucosamine suppressed the IL- 8 production and ICAM-1 expression by TNF- $\alpha$-activated HT-29 cells. Furthermore, glucosamine inhibited the TNF- $\alpha$-induced phosphorylation of p38MAPK and NF- $\mathrm{BB}$ p65, and the nuclear translocation of $\mathrm{NF}-\kappa \mathrm{B}$ in the cells. Thus, glucosamine demonstrates inhibitory actions on the inflammatory and signaling molecules (IL-8, ICAM-1, p38MAPK and NF-кB) in intestinal epithelial cells. However, glucosamine did not essentially affect the binding of TNF- $\alpha$ to its receptor on HT-29 cells. Together, these observations suggest that glucosamine may have the potential to exhibit an anti-inflammatory action on intestinal epithelial cells, by possibly interfering with the activation signaling downstream of the ligand/receptor binding.
\end{abstract}

\section{Introduction}

Although the exact etiology and pathogenesis of inflammatory bowel diseases (IBD), such as ulcerative colitis (UC) and

Correspondence to: Dr Isao Nagaoka, Department of Host Defense and Biochemical Research, Juntendo University, School of Medicine, 2-1-1 Hongo, Bunkyo-ku, Tokyo 113-8421, Japan

E-mail: nagaokai@med.juntendo.ac.jp

Key words: glucosamine, intestinal epithelial cells, IL-8, ICAM-1, TNF- $\alpha$
Crohn's disease, remain obscure, there is substantial evidence that proinflammatory cytokines including tumor necrosis factor- $\alpha(\mathrm{TNF}-\alpha)$ play a key role in the inflammatory process $(1,2)$; TNF- $\alpha$ production has been shown to increase in the intestinal mucosa, serum, lamina propria mononuclear cells and peripheral blood mononuclear cells in patients with IBD (3-6). At present, medical treatment of IBD relies mainly on traditional drugs: aminosalicylates, corticosteroids and immunosuppressants. These drugs reduce inflammatory injury and attenuate the expression of some proinflammatory molecules (1). However, their side effects and systemic actions are so severe that they disturb the life quality of patients, particularly during long-term treatment. Thus, it is important to develop an optimal therapy for IBD.

Intestinal epithelial cells play an important role in the mucosal immune reaction during gut inflammation. Proinflammatory cytokines activate intestinal epithelial cells to produce interleukin-8 (IL-8) and express intercellular adhesion molecule-1 (ICAM-1) $(7,8)$. IL-8 is an important inflammatory mediator that belongs to the CXC chemokine family and plays a role in the initiation and maintenance of IBD by recruiting neutrophils into the inflamed tissues (9-13). ICAM-1 is also involved in the tissue damage and neutrophil infiltration in the inflamed colon $(14,15)$. IL- 8 and ICAM-1 expression is up-regulated by proinflammatory cytokines via the phosphorylation of mitogen-activated protein kinases (MAPKs) and activation of nuclear factor- $\kappa \mathrm{B}(\mathrm{NF}-\kappa \mathrm{B})(8,16)$. Furthermore, MAPKs and NF- $\mathrm{KB}$ are reported to be activated in IBD (17).

Glucosamine, a naturally-occurring amino monosaccharide, is present in the connective and cartilage tissues and contributes to maintaining the strength, flexibility and elasticity of these tissues. Thus, glucosamine has been widely used to treat osteoarthritis in humans. Several clinical trials in osteoarthritis have shown the significant symptom-modifying effect of glucosamine (18). According to previous biochemical and pharmacological studies, administration of glucosamine normalizes cartilage metabolism, so as to stimulate the synthesis and inhibit the degradation of proteoglycans, and to restore articular function $(19,20)$. In addition to its chondroprotective action, glucosamine is expected to exert anti-inflammatory actions by inhibiting neutrophil functions such as superoxide generation, 
phagocytosis, granule enzyme release and chemotaxis (21). Moreover, glucosamine was demonstrated to prolong allogeneic cardiac allograft survival by suppressing the activation of T-lymphoblasts and dendritic cells (22). In addition, glucosamine effectively inhibits cytotoxic Tlymphocyte function and natural killer cell cytotoxicity (23). Furthermore, glucosamine has been reported to suppress ADP-mediated platelet activation (24). However, the antiinflammatory effect of glucosamine on intestinal epithelial cells is poorly understood.

In the present study, to address this issue, we investigated the effect of glucosamine on the activation of intestinal epithelial cells using a human colonic epithelial cell line HT-29.

\section{Materials and methods}

Reagents. Human recombinant TNF- $\alpha$ was purchased from R\&D Systems (Minneapolis, MN). D-glucosamine hydrochloride was supplied by Koyo Chemical Co., Ltd., (Tokyo, Japan).

Cell culture. A human colonic epithelial cell line HT-29 was obtained from the American Type Culture Collection (Manassas, VA). Cells were grown at $37^{\circ} \mathrm{C}$ in a $\mathrm{CO}_{2}$ incubator in McCoy's 5A medium (Sigma Chemical, St. Louis, MO) containing $10 \%$ fetal bovine serum (FBS, endotoxin level $<10 \mathrm{EU} / \mathrm{ml} / \mathrm{ml}$; Cell Culture Technologies, Herndon, VA), penicillin $(100 \mathrm{U} / \mathrm{ml})$ and streptomycin $(0.1 \mathrm{mg} / \mathrm{ml})$. Cells were grown in 60-mm tissue culture dishes (Iwaki, Tokyo, Japan).

Measurement of IL-8 production. HT-29 cells were plated at $5 \times 10^{5}$ cells/well in 35-mm tissue culture dishes in McCoy's $5 \mathrm{~A}$ medium containing $10 \% \mathrm{FBS}$ for $48 \mathrm{~h}$ at $37^{\circ} \mathrm{C}$. After washing twice with phosphate-buffered saline (PBS; $137 \mathrm{mM}$ $\mathrm{NaCl}, 2.7 \mathrm{mM} \mathrm{KCl}, 8.1 \mathrm{mM} \mathrm{Na} \mathrm{HPO}_{4}, 1.5 \mathrm{mM} \mathrm{KH} \mathrm{PO}_{4}$, $\mathrm{pH}$ 7.4), cells were incubated in McCoy's 5A medium containing $1 \% \mathrm{FBS}$ in the absence or presence of $0.1-10 \mathrm{mM}$ glucosamine, and then stimulated with TNF- $\alpha(10 \mathrm{ng} / \mathrm{ml})$ for $12 \mathrm{~h}$. IL-8 in the culture supernatants was quantified by a sandwich enzyme-linked immunosorbent assay (ELISA) using the DuoSet ELISA Development kit (R\&D Systems) as described previously (16). Microtiter plates (96-well half area flat bottom; Corning, Acton, MA) were coated with $4 \mu \mathrm{g} / \mathrm{ml}$ capture antibody $(25 \mu \mathrm{l} /$ well, diluted in PBS) overnight at room temperature. After washing with PBS$0.05 \%$ Tween-20, plates were blocked with $1 \%$ bovine serum albumin (BSA) in PBS for $1 \mathrm{~h}$ at room temperature. The plates were then washed, $25 \mu \mathrm{l} /$ well culture supernatants or standards (15-2000 pg/ml) was added, and incubated for $2 \mathrm{~h}$ at room temperature. After washing, the plates were incubated with $20 \mathrm{ng} / \mathrm{ml}$ of biotinylated goat anti-human IL-8 antibody for $2 \mathrm{~h}$ at room temperature. After washing, streptavidin-horseradish peroxidase was added at $25 \mu \mathrm{l} /$ well, followed by $25 \mu \mathrm{l}$ of tetramethyl benzidine (TMB) liquid substrate. The reaction was terminated with $1 \mathrm{M} \mathrm{H}_{2} \mathrm{SO}_{4}$, and plates were read immediately at 450 and $570 \mathrm{~nm}$ with a microplate reader (Model 680; Bio-Rad, Hercules, CA). The detection limit was $<15 \mathrm{pg} / \mathrm{ml}$.
Measurement of ICAM-1 expression. HT-29 cells were stimulated with TNF- $\alpha$ in the absence or presence of glucosamine as described above. After washing with PBS, the cells were harvested in $0.3 \mathrm{ml}$ of lysis buffer $(1 \%$ Triton X-100, 0.5\% Nonidet P-40, 10 mM Tris-HCl, pH 7.4, $150 \mathrm{mM} \mathrm{NaCl}, 1 \mathrm{mM}$ EDTA, $1 \mathrm{mM}$ EGTA) containing 1/25 v/v Complete ${ }^{\mathrm{TM}}$ (Roche Diagnostic Systems, Mannheim, Germany) and 1/100 v/v Phosphatase Inhibitor Cocktail ${ }^{\mathrm{TM}}$ (Nacalai Tesque, Kyoto, Japan). After sonication, the lysates were centrifuged at $12,000 \mathrm{x}$ g for $10 \mathrm{~min}$. The protein concentrations were determined with a commercial BCA protein assay kit (Pierce, Rockford, IL) by using BSA as a standard. The lysates were mixed with an equal volume of 2X SDS-PAGE (sodium dodecyl sulfate-polyacrylamide gel electrophoresis) sample buffer (125 mM Tris, pH 6.8, 20\% glycerol, 4\% SDS, 10\% B-mercaptoethanol, $0.01 \%$ bromophenol blue) and boiled for $3 \mathrm{~min}$. Aliquots containing $10 \mu \mathrm{g}$ protein were subjected to SDS-PAGE on $10 \%$ acrylamide gels. After electrophoresis, proteins were transferred for $45 \mathrm{~min}$ at $50 \mathrm{~V}$ in transfer buffer (10 mM CAPS, pH 11.0, $10 \%$ methanol) onto Immobilon-P polyvinylidene difluoride membrane (Millipore, Bedford, MA). The blots were blocked for $1 \mathrm{~h}$ in Tris-buffered saline (TBST; $\mathrm{pH} 7.6,0.1 \%$ Tween-20) containing $5 \%$ skim milk at room temperature and incubated overnight at $4^{\circ} \mathrm{C}$ with rabbit anti-human ICAM-1 Ab (H-108, Santa Cruz Biotechnology). The blots were further probed with horseradish peroxidase (HRP)-conjugated anti-rabbit IgG (Chemicon International, Temecula, CA), and ICAM-1 was finally detected with SuperSignal ${ }^{\circledR}$ West Pico Chemiluminescent substrate (Pierce). To confirm equal loading of protein, the antibodies were stripped from the membranes using WB Stripping Solution Strong (Nacalai Tesque), and GAPDH was detected with mouse anti-GAPDH monoclonal antibody (MAB374, Chemicon International) and HRP-conjugated goat anti-mouse $\mathrm{IgG} / \mathrm{IgM}$ (Chemicon International). The detection bands were quantified by the Fujifilm Luminescent Image Analyzer LAS 3000 (Fujifilm, Tokyo, Japan).

Phosphorylation of p38MAPK. After incubation overnight at $37^{\circ} \mathrm{C}$ in McCoy's 5A medium containing 1\% FBS, HT-29 cells were stimulated with $\mathrm{TNF}-\alpha(10 \mathrm{ng} / \mathrm{ml})$ for $10 \mathrm{~min}$ in the presence or absence of glucosamine $(0.1-10 \mathrm{mM})$, and cell lysates were prepared using Mono Q buffer (1.08 $\mathrm{g}$ of $\beta$ glycerophosphate, $38.04 \mathrm{mg}$ EGTA, $0.5 \mathrm{ml}$ of Triton X-100, and $200 \mu \mathrm{l}$ of $1 \mathrm{M} \mathrm{MgCl}_{2}$ per $\left.100 \mathrm{ml}\right)$. Supernatants of cell lysates (10 $\mu \mathrm{g}$ protein) were subjected to $10 \%$ SDS-PAGE, and phosphorylated p38MAPK was detected by probing with mouse anti-phosphorylated p38MAPK monoclonal antibody (pT180/pY182; BD Biosciences Pharmingen, San Diego, CA) and HRP-conjugated goat anti-mouse $\mathrm{IgG} / \mathrm{IgM}$. After stripping, the p38MAPK protein contained in each sample was detected by reprobing with mouse anti-p38 MAPK (p38/ SAPK $2 \alpha$; BD Biosciences Pharmingen) monoclonal antibody and HRP-conjugated goat anti-mouse IgG/IgM.

Phosphorylation of $N F-\kappa B$. After incubation overnight at $37^{\circ} \mathrm{C}$ in McCoy's 5A medium containing 1\% FBS, HT-29 cells were stimulated with TNF- $\alpha(10 \mathrm{ng} / \mathrm{ml})$ for $10 \mathrm{~min}$ in the presence or absence of glucosamine (0.1-10 $\mathrm{mM})$, and 
A

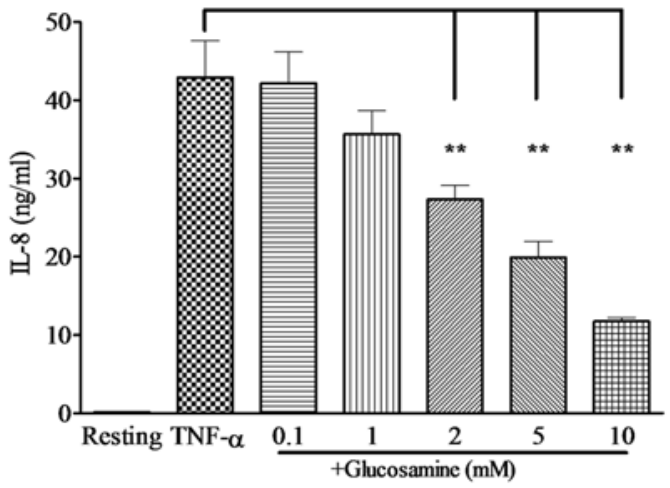

B
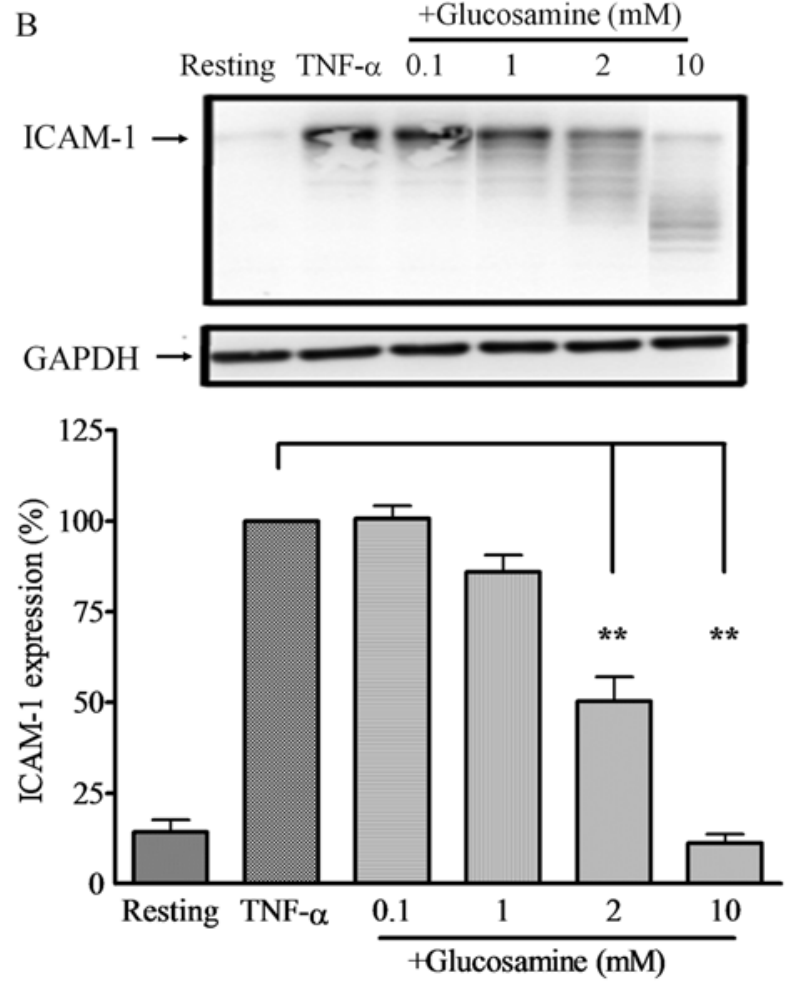

Figure 1. Effect of glucosamine on IL-8 production and ICAM-1 expression by TNF- $\alpha$-activated HT-29 cells. HT- 29 cells were incubated without (Resting) or with $10 \mathrm{ng} / \mathrm{ml} \mathrm{TNF}-\alpha$ for $12 \mathrm{~h}$ at $37^{\circ} \mathrm{C}$ in the absence or presence of $0.1-10 \mathrm{mM}$ glucosamine (+Glucosamine). (A) IL-8 in the culture supernatants was quantified by ELISA. (B) The cell lysates were subjected to $10 \%$ SDS-PAGE. ICAM-1 expression was detected by probing with rabbit anti-human ICAM-1 antibody and HRP-conjugated goat antirabbit IgG. GAPDH as a loading control was detected by reprobing with mouse anti-GAPDH monoclonal antibody and HRP-conjugated goat antimouse $\mathrm{IgG} / \mathrm{IgM}$. ICAM-1 expression was expressed as a percentage of that of TNF- $\alpha$-stimulated cells without glucosamine (TNF- $\alpha$ ). Data represent the mean \pm SEM of six separate experiments. Values were compared between the absence and presence of glucosamine (TNF- $\alpha$ vs. +Glucosamine) ${ }^{* *} \mathrm{P}<0.01$.

cell lysates were prepared using Mono Q buffer as described above. In some experiments, to prepare nuclear extracts, TNF- $\alpha$-stimulated HT-29 cells were washed with ice-cold PBS containing 1/20 v/v phosphatase inhibitor buffer (PIB; $125 \mathrm{mM} \mathrm{NaF}, 250 \mathrm{mM}$ ß-glycerophosphate, $250 \mathrm{mM}$ paranitrophenyl phosphate, $25 \mathrm{mM} \mathrm{NaVO}_{3}$ ), and harvested in $1 \mathrm{ml}$ of PBS containing $1 / 20 \mathrm{v} / \mathrm{v}$ PIB. After being transferred into a microtube, cells were centrifuged at $300 \mathrm{x}$ g for $5 \mathrm{~min}$ at $4^{\circ} \mathrm{C}$ and resuspended in $1 \mathrm{ml}$ of ice-cold hypotonic buffer
(HB; 20 mM HEPES, pH 7.5, $5 \mathrm{mM} \mathrm{NaF}, 10 \mu \mathrm{M}$ $\mathrm{Na}_{2} \mathrm{MoO}_{4}, 0.1 \mathrm{mM}$ EDTA). Then, cells were incubated for $15 \mathrm{~min}$ on ice and $50 \mu \mathrm{l}$ of $10 \%$ Nonidet P-40 was added, followed by gentle mixing. After centrifugation at $500 \mathrm{x} \mathrm{g}$ for $1 \mathrm{~min}$, the nuclear fraction (pellet) was resuspended in $50 \mu 1$ of lysis buffer (20 mM HEPES, pH 7.5, $400 \mathrm{mM} \mathrm{NaCl}$, $0.1 \mathrm{mM}$ EDTA, $10 \mathrm{mM} \mathrm{NaF}, 10 \mu \mathrm{M} \mathrm{Na}{ }_{2} \mathrm{MoO}_{4}, 1 \mathrm{mM}$ $\mathrm{NaVO}_{3}, 20 \%$ glycerol, $10 \mathrm{mM}$ para-nitrophenyl phosphate, $10 \mathrm{mM}$ ß-glycerophosphate) containing $1 \mathrm{mM}$ dithiothreitol and 1/100 v/v Protease Inhibitor Cocktail (Sigma Chemical), and extracted for $30 \mathrm{~min}$ at $4^{\circ} \mathrm{C}$. The mixtures were centrifuged at $14,000 \mathrm{x} \mathrm{g}$ for $10 \mathrm{~min}$ at $4^{\circ} \mathrm{C}$, and the supernatants (nuclear extracts) were stored at $-80^{\circ} \mathrm{C}$ until use. Supernatants of cell lysates or nuclear extracts ( $10 \mu \mathrm{g}$ protein) were subjected to $10 \%$ SDS-PAGE, and phosphorylated NF-кB was detected by probing with rabbit anti-phospho-NF-кB p65 Ab (Ser536; Cell Signaling Technology, Danvers, MA) and HRP-conjugated goat anti-rabbit IgG.

Assay for the binding of TNF- $\alpha$ to HT-29. HT-29 cells ( $5 \times 10^{5}$ cells/ well) were cultured in McCoy's 5A medium containing 10\% FBS in 6-well plates for $72-96 \mathrm{~h}$ to become confluent. The cells were incubated with $0.1 \mathrm{pmol}\left[{ }^{125} \mathrm{I}\right]$-recombinant TNF- $\alpha$ ( $753 \mathrm{Ci} / \mathrm{mmol}$; PerkinElmer Life Sciences, Boston, MA) in the absence or presence of glucosamine (0.1-10 mM) for $2 \mathrm{~h}$ at $4^{\circ} \mathrm{C}$. After washing 3 times with PBS, the cells were stripped with $0.25 \%$ trypsin-EDTA (Invitrogen, Carlsbad, $\mathrm{CA}$ ), and radioactivity (total binding) was measured by scintillation counting. Nonspecific binding was defined as the binding measured in the presence of excess unlabeled TNF- $\alpha$ (100 pmol), and specific binding was defined as the difference between total binding and nonspecific binding (25).

Statistical analysis. Results are expressed as the mean \pm SEM. Statistical analyses were performed using one-way ANOVA (and non-parametric), and statistical significance was accepted at $\mathrm{P}<0.05$.

\section{Results}

Effect of glucosamine on IL-8 production and ICAM-1 expression by $H T-29$. We first examined the effect of glucosamine on the IL- 8 production and ICAM-1 expression by intestinal epithelial cells. TNF- $\alpha$ stimulation markedly induced the production of IL- 8 and expression of ICAM- 1 by HT-29 cells, as analyzed by ELISA and Western blotting, respectively (Fig. 1A and B). Importantly, glucosamine dosedependently suppressed the IL-8 production and ICAM-1 expression $(\mathrm{P}<0.01$ at $2-10 \mathrm{mM})$. Notably, treatment with glucosamine $(\sim 10 \mathrm{mM})$ reduced the molecular mass of ICAM-1 from 100-110 kDa (TNF- $\alpha$ stimulation without glucosamine) to $\sim 55 \mathrm{kDa}$.

Effect of glucosamine on the binding of TNF- $\alpha$ to HT-29 cells. TNF- $\alpha$ activates cells via the binding to its receptors (25). Moreover, it has been reported that glucosamine partly inhibits the binding of ADP and IL-1ß to the receptors on platelets and synovial cells, respectively $(24,26)$. Next, we determined whether the inhibitory effect of glucosamine on 


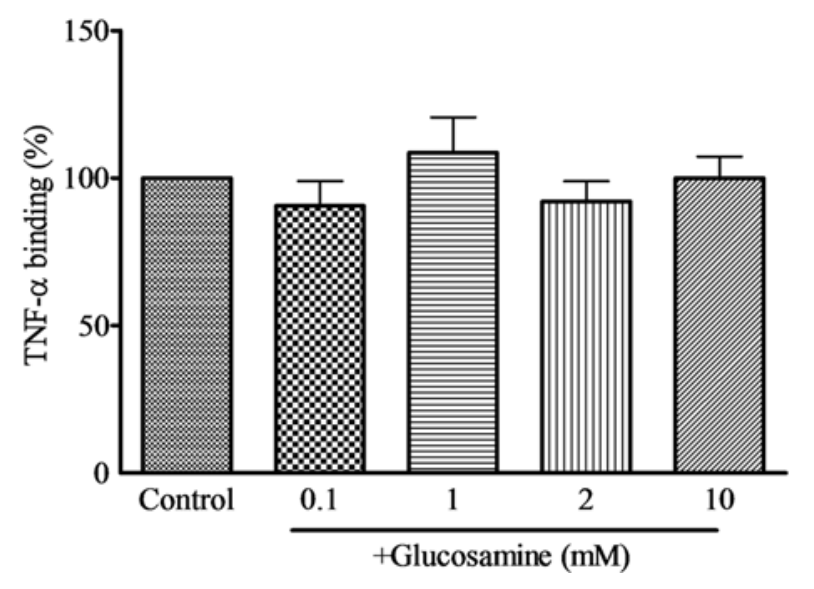

Figure 2. Effect of glucosamine on the binding of TNF- $\alpha$ to HT-29 cells. HT-29 cells were incubated with $0.1 \mathrm{pmol}\left[{ }^{125} \mathrm{I}\right]$-recombinant TNF- $\alpha$ in the absence (control) or presence (+Glucosamine) of glucosamine (0.1-10 mM) at $4{ }^{\circ} \mathrm{C}$ for $2 \mathrm{~h}$. After washing with PBS, the cells were stripped with $0.25 \%$ trypsin-EDTA, and radioactivity was measured by scintillation counting. The specific binding of TNF- $\alpha$ is expressed as a percentage of the control $(831.1 \pm 213.9 \mathrm{cpm})$. Data represent the mean \pm SEM of eight separate experiments.

intestinal epithelial cell activation results from the suppression of TNF- $\alpha$ binding to the receptors using ${ }^{125}$ I-labeled TNF- $\alpha$. As shown in Fig. 2, glucosamine did not essentially affect the specific binding of TNF- $\alpha$ to its receptor on HT-29 cells. Thus, it is unlikely that glucosamine inhibits the TNF- $\alpha-$ induced activation of intestinal epithelial HT-29 cells (IL-8 production and ICAM-1 expression) via action on the ligand/receptor binding.

Effect of glucosamine on the phosphorylation of p38MAPK and activation of $N F-\kappa B$. It has been reported that TNF- $\alpha$ signals to increase phosphorylation (activation) of signaling proteins, including p38MAPK and NF- $\mathrm{BB}$, and their activation is necessary for cytokine production and adhesion molecule expression $(17,27)$. To clarify the mechanism for the action of glucosamine, we investigated its effect on signaling molecules. As shown in Fig. 3, TNF- $\alpha$ stimulation strikingly enhanced the phosphorylation of p38MAPK in HT-29 cells. Glucosamine dose-dependently inhibited the TNF- $\alpha$ stimulated phosphorylation of p38MAPK in HT-29 cells $(\mathrm{P}<0.01$ at $2-10 \mathrm{mM})$. In contrast, the content of $\mathrm{p} 38 \mathrm{MAPK}$ protein as a loading control was not affected by glucosamine.

$\mathrm{NF}_{-} \mathrm{\kappa B}$ is also an important regulator for the genes encoding cytokines and adhesion molecules $(28,29)$. Thus, we determined the effects of glucosamine on the phosphorylation and nuclear translocation of phosphorylated NF-кB p65 by Western blotting. As shown in Fig. 4A, glucosamine dosedependently suppressed the phosphorylation of NF-кB p65 in the cells, although the effect was not significant. Notably, glucosamine further suppressed the nuclear translocation of phosphorylated NF-кB p65 (P<0.05 at 2-10 mM) (Fig. 4B).

These observations suggest that glucosamine inhibits the TNF- $\alpha$-induced activation of intestinal epithelial HT-29 cells (IL- 8 production and ICAM-1 expression) possibly by suppressing the signaling (phosphorylation of p38MAPK and $\mathrm{NF}-\kappa \mathrm{B}$, and nuclear translocation of phosphorylated NF- $\mathrm{KB}$ ), downstream of the ligand/receptor binding.
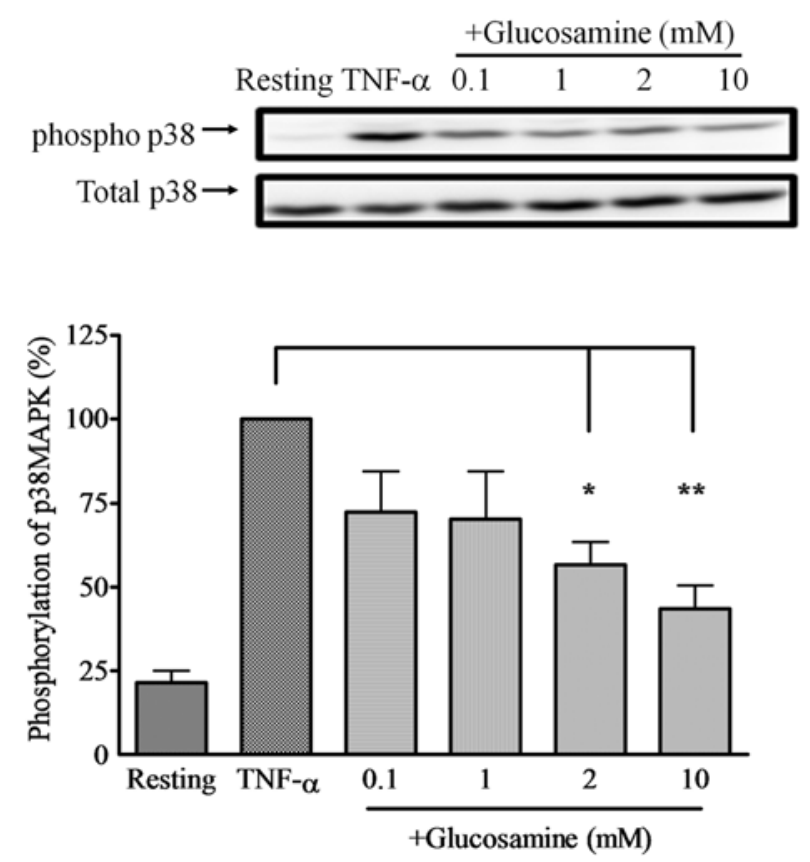

Figure 3. Effect of glucosamine on the phosphorylation of p38MAPK. HT-29 cells were incubated without (Resting) or with $10 \mathrm{ng} / \mathrm{ml} \mathrm{TNF-} \alpha$ for $10 \mathrm{~min}$ in the absence or presence of $0.1-10 \mathrm{mM}$ glucosamine (+Glucosamine). The cell lysates were subjected to 10\% SDS-PAGE, and phosphorylated p38MAPK was detected by probing with mousephosphorylated p38MAPK (pT180/pY182) monoclonal antibody and HRPconjugated goat anti-mouse IgG/IgM. p38MAPK as a loading control was detected by reprobing with mouse anti-p38MAPK (p38/SAPK2 $\alpha$ ) monoclonal antibody and HRP-conjugated goat anti-mouse $\operatorname{IgG/IgM}$. The level of phosphorylated p38MAPK was expressed as a percentage of that of TNF- $\alpha$-stimulated cells without glucosamine $(\mathrm{TNF}-\alpha)$. Data represent the mean \pm SEM of four separate experiments. Values were compared between the absence and presence of glucosamine (TNF- $\alpha$ vs. +Glucosamine). ${ }^{*} \mathrm{p}<0.05,{ }^{* *} \mathrm{P}<0.01$.

\section{Discussion}

Intestinal epithelial cells play an important role in the mucosal immune reaction in IBD by producing and expressing chemokines and adhesion molecules, such as IL-8 and ICAM-1, which are involved in neutrophil infiltration and tissue damage in the inflamed colon $(1,30)$. Glucosamine, a naturally occurring amino monosaccharide, is widely used to treat osteoarthritis in humans. Furthermore, glucosamine exhibits an anti-inflammatory action by inhibiting neutrophil functions (21). In the present study, to evaluate the antiinflammatory action of glucosamine on intestinal epithelial cells, we examined the effects of glucosamine on intestinal epithelial cell activation using a human colonic epithelial cell line HT-29. The results indicate that glucosamine suppresses the IL- 8 production and ICAM- 1 expression by TNF- $\alpha-$ activated HT-29 cells. Furthermore, glucosamine inhibited the TNF- $\alpha$-induced phosphorylation of p38MAPK and NF- $\kappa \mathrm{B}$ p65 in the cells.

TNF- $\alpha$ plays a pivotal role in the mucosal immune response during the inflammatory process of IBD and experimental colitis. Lamina propria mononuclear cells, including macrophages and lymphocytes, are the major source of TNF- $\alpha$ $(6,31)$. Moreover, chemokines and adhesion molecules such as IL- 8 and ICAM-1 are involved in the pathogenesis of IBD 

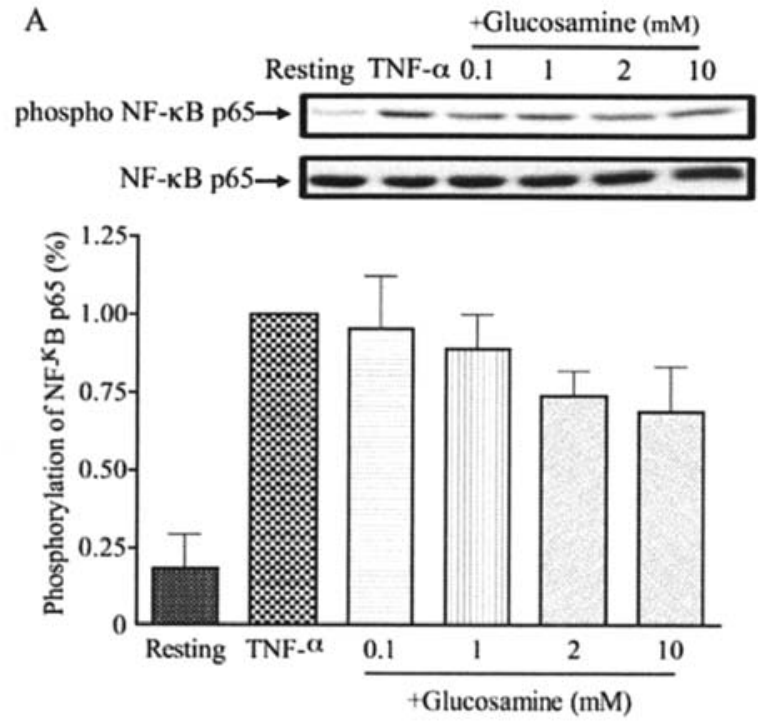

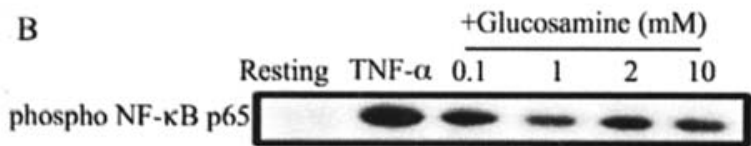

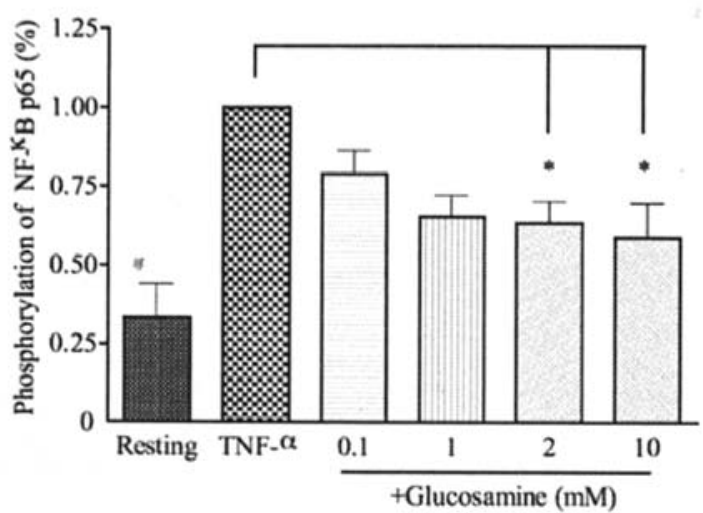

Figure 4. Effect of glucosamine on the phosphorylation of NF-кB p65. НT-29 cells were incubated without (Resting) or with $10 \mathrm{ng} / \mathrm{ml} \mathrm{TNF}-\alpha$ for $10 \mathrm{~min}$ in the absence or presence of 0.1-10 mM glucosamine (+Glucosamine). (A) The cell lysates were subjected to $10 \%$ SDS-PAGE, and phosphorylated

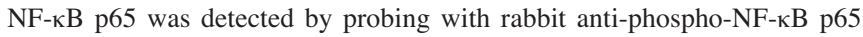
$\mathrm{Ab}$ (Ser536) and HRP-conjugated goat anti-rabbit IgG. (B) The nuclear extracts were subjected to $10 \%$ SDS-PAGE, and phosphorylated NF- $\kappa$ B was similarly detected. The level of phosphorylated NF- $\mathrm{kB}$ p 65 was expressed as a percentage of that of TNF- $\alpha$-stimulated cells without glucosamine (TNF- $\alpha$ ). Data represent the mean \pm SEM of three to five separate experiments. Values were compared between the absence and presence of glucosamine (TNF- $\alpha$ vs. +Glucosamine). ${ }^{*} \mathrm{P}<0.05$.

by recruiting neutrophils into the inflamed mucosal tissues, which facilitates the formation of crypt abscesses observed in IBD $(1,30,32)$. In addition, MAPKs (extracellular signalregulated kinases, Jun N-terminal kinases, p38MAPK) are implicated in IBD (33). Phosphorylation of MAPKs leads to the downstream activation of transcription factors (such as $\mathrm{NF}-\kappa \mathrm{B})$, which upregulate the expression of cytokines/ chemokines. Notably, among MAPKs, p38MAPK is highly activated in inflamed colonic mucosa of IBD (34). NF-кB also plays a central role in the induction of various inflammatory mediators and adhesion molecules. In unstimulated cells, NF- $\mathrm{kB}$ (a dimer composed of the p65 and p50 subunits), which is bound to the member of the IкB inhibitory protein family, is confined to the cytoplasm. Upon stimulation, IкB is rapidly released from the complex, and then $N F-\kappa B$ is phosphorylated and translocated into the nucleus (35-37). Importantly, NF-кB activity is increased in the colon during active episodes of IBD (38). The present study revealed that TNF- $\alpha$ induced the production of IL- 8 , expression of ICAM-1, phosphorylation of p38MAPK and $\mathrm{NF}-\kappa \mathrm{B}$, and nuclear translocation of $\mathrm{NF}-\kappa \mathrm{B}$ in intestinal epithelial HT-29 cells, and that glucosamine suppressed these changes. Thus, glucosamine has a potential to exert inhibitory actions on the inflammatory and signaling molecules (IL-8, ICAM-1, p38MAPK and NF-кB) in intestinal epithelial cells, which are involved in the initiation and maintenance of IBD. Moreover, it has been reported that glucosamine inhibits neutrophil functions such as superoxide anion generation, granule enzyme release, chemotaxis and up-regulation of CD11b (21). These observations likely suggest that glucosamine may exhibit a protective action on IBD by suppressing the intestinal epithelial cell and neutrophil activation. In this context, it is noteworthy that glucosamine ameliorated the clinical symptoms (based on the disease activity index), and suppressed the increase of the serum CINC-1 level and upregulation of $\mathrm{CD} 11 \mathrm{~b}$ on peripheral blood neutrophils in our preliminary experiments (data not shown) using a DSS (dextran sulfate sodium)-induced rat colitis model (32).

It is known that the binding of TNF- $\alpha$ to its cell surface receptor causes a cascade of signaling events including the activation of $\mathrm{p} 38 \mathrm{MAPK}$ and NF- $\mathrm{KB}(27,38)$. We previously revealed that glucosamine partly inhibits the binding of ADP and IL-1ß to their receptors on platelets and synovial cells, respectively $(24,26)$. However, glucosamine did not essentially affect the specific binding of TNF- $\alpha$ to its receptor on HT-29 cells (Fig. 2). Thus, glucosamine is unlikely to inhibit the TNF- $\alpha$-induced HT-29 cell activation via action on the ligand/receptor binding. It is now recognized that the addition of $O$-linked $N$-acetylglucosamine $(O$-GlcNAc) to serine and/or threonine residues of cytoplasmic and nuclear target proteins modulates cellular functions, such as nuclear transport, transcription, translation and cell signaling (39-41), and that glucosamine enhances the level of $O$-GlcNAcmodified proteins in cells (42). We tried to detect $O$-GlcNAc modification in HT-29 cells by Western blotting using anti$O$-GlcNAc monoclonal antibody (Covance Research Products, Princeton, NJ), and found that glucosamine but not TNF- $\alpha$ increased the $O$-GlcNAc levels in HT-29 cells (data not shown); the effect of glucosamine on the $O$-GlcNAc modification was negatively correlated with that on the intestinal epithelial cell activation (production of IL-8, expression of ICAM-1, phosphorylation of p38MAPK and $\mathrm{NF}-\kappa \mathrm{B}$ and nuclear translocation of NF- $\mathrm{B}$ ). Furthermore, we confirmed that alloxan (an inhibitor of $O$-GlcNAc transferase, an $O$-GlcNAc modification forming enzyme) abrogated the suppressive action of glucosamine on IL- 8 production by TNF- $\alpha$-stimulated HT-29 cells (data not shown). Together, these observations suggest that $O$-GlcNAc modification is one of the possible mechanisms for the glucosamine-induced suppression of intestinal epithelial cell activation. 
ICAM-1 is a heavily $N$-glycosylated protein containing 505 amino acids with a predicted molecular mass of $55 \mathrm{kDa}$; however, the actual molecular mass ranges from 76 to $114 \mathrm{kDa}$ depending on the degree of glycosylation at eight potential $\mathrm{N}$-glycosylation sites $(43,44)$. In this study, glucosamine ( $\sim 10 \mathrm{mM})$ reduced the molecular mass of ICAM-1 from 100$110 \mathrm{kDa}$ to $\sim 55 \mathrm{kDa}$, suggesting that glucosamine may interfere with the N-glycosylation of the ICAM-1 molecule in HT-29 cells. Consistent with this, it has been recently reported that glucosamine treatment prevents the $\mathrm{N}$-glycosylation of cyclooxygenase-2 (an $N$-glycoprotein) in IL-1ßstimulated A549 cells and reduces the molecular mass from $72-74$ to $\sim 66 \mathrm{kDa}$ (a predicted molecular mass without glycosylation) (42). Thus, it is also possible that glucosamine exhibits the suppressive action on the intestinal epithelial cells by affecting the glycosylation of $N$-glycosylated proteins.

In conclusion, the present study has revealed that glucosamine suppresses intestinal epithelial cell activation by inhibiting the production, expression or activation of inflammatory and signaling molecules (IL-8, ICAM-1, p38MAPK and NF-кB). Thus, glucosamine has the potential to exhibit an anti-inflammatory action on IBD. The in vivo effect of glucosamine on inflammatory bowel diseases should be carefully evaluated in animal models and patients in the future.

\section{Acknowledgements}

This work was supported in part by a grant from the Foundation for Pre-symptomatic Medicine and Anti-aging, Institute of Gerontology, Hakujikai, Japan.

\section{References}

1. Li JH, Yu JP, Yu HG, Xu XM, Yu LL, Liu J and Luo HS: Melatonin reduces inflammatory injury through inhibiting $\mathrm{NF}-\kappa \mathrm{B}$ activation in rats with colitis. Mediators Inflamm 4: 185-193, 2005.

2. Sans M, Panes J, Ardite E, Elizalde JI, Arce Y, Elena M, Palacin A, Fernandez-Checa JC, Anderson DC, Lobb R and Pique JM: VCAM-1 and ICAM-1 mediate leukocyte-endothelial cell adhesion in rat experimental colitis. Gastroenterology 116 : 874-883, 1999.

3. Ishiguro Y: Mucosal proinflammatory cytokine production correlates with endoscopic activity of ulcerative colitis. J Gastroenterol 34: 66-74, 1999.

4. Maeda M, Watanabe N, Neda H, Yamaguchi N, Okamoto T, Sasaki H, Tsuji Y, Akiyama S, Tsuji N and Niitsu Y: Serum tumor necrosis factor activity in inflammatory bowel disease. Immunopharmacol Immunotoxicol 14: 451-461, 1992.

5. Nakamura K, Honda K, Mizutani T, Akiho H and Harada N: Novel strategies for the treatment of inflammatory bowel disease: Selective inhibition of cytokines and adhesion molecules. World J Gastroenterol 12: 4628-4635, 2006.

6. Neuman MG: Signaling for inflammation and repair in inflammatory bowel disease. J Gastroenterol 13: 309-316, 2004.

7. Yang SK, Eckmann L, Panja A and Kagnoff MF: Differential and regulated expression of $\mathrm{C}-\mathrm{X}-\mathrm{C}, \mathrm{C}-\mathrm{C}$, and $\mathrm{C}$-chemokines by human colon epithelial cells. Gastroenterology 113: 1214-1223, 1997.

8. Jijon HB, Panenka WJ, Madsen KL and Parsons HG: MAP kinases contribute to IL-8 secretion by intestinal epithelial cells via a posttranscriptional mechanism. Am J Physiol Cell Physiol 283: C31-C41, 2002.

9. Kang OH, Kim JA, Choi YA, Park HJ, Kim DK, An YH, Choi SC, Yun KJ, Nah YH, Cai XF, Kim YH, Bae KH and Lee YM: Inhibition of interleukin-8 production in the human colonic epithelial cell line HT-29 by 18ß-glycyrrhetinic acid. Int J Mol Med 15: 981-985, 2005.
10. Mazzucchelli L, Hauser C, Zgraggen K, Wagner H, Hess M, Laissue JA and Muller C: Expression of interleukin- 8 gene in inflammatory bowel disease is related to the histological grade of active inflammation. Am J Pathol 144: 997-1007, 1994.

11. Mahida YR, Ceska M, Effenberger F, Kurlak L, Lindley I and Hawkey CJ: Enhanced synthesis of neutrophil-activating peptide-1/interleukin-8 in active ulcerative colitis. Clin Sci 82: 273-275, 1992.

12. Izzo RS, Witkon K, Chen AI, Hadjiyane C, Weinstein MI and Pellecchia C: Neutrophil-activating peptide (interleukin-8) in colonic mucosa from patients with Crohn's disease. Scand J Gastroenterol 28: 296-300, 1993.

13. Mitsuyama K, Toyonaga A, Sasaki E, Watanabe K, Tateishi H, Nishijima T, Saiki T, Ikeda H, Tsuruta O and Tanikawa K: IL-8 as an important chemoattractant for neutrophils in ulcerative colitis and Crohn's disease. Clin Exp Immunol 96: 432-436, 1994.

14. Nielsen OH, Vainer B, Madsen SM, Seidelin JB and Heegaard HHN: Established and emerging biological activity markers of inflammatory bowel disease. Am J Gastroenterol 95: 359-367, 2000.

15. Ikeda Y, Ito M, Matsuu M, Shichijo K, Fukuda E, Nakayama T, Nakashima M, Naito S and Sekine I: Expression of ICAM-1 and acute inflammatory cell infiltration in the early phase of radiation colitis in rats. J Radiat Res 41: 279-291, 2000.

16. Kuldo JM, Westra J, Asgeirsdottir SA, Kok RJ, Oosterhuis K, Rots MG, Schouten JP, Limburg PC and Molema G: Differential effects of NF- $\mathrm{KB}$ and p38 MAPK inhibitors and combinations there of on TNF- $\alpha$ - and IL-1ß-induced proinflammatory status of endothelial cells in vitro. Am J Physiol Cell Physiol 289: C1229-C1239, 2005.

17. Hollenbach E, Neumann M, Vieth M, Roessner A, Malfertheiner P and Naumann M: Inhibition of p38 MAP kinase- and RICK/NF- $\kappa$ B-signaling suppresses inflammatory bowel disease. FASEB J 18: 1550-1552, 2004.

18. Rafi MM, Yadav PN and Rossi AO: Glucosamine inhibits LPSinduced COX-2 and iNOS expression in mouse macrophage cells (RAW 264.7) by inhibition of p38-MAP kinase and transcription factor NF-кB. Mol Nutr Food Res 51: 587-593, 2007.

19. Oegema TR Jr, Deloria LB, Sandy JD and Hart DA: Effect of oral glucosamine on cartilage and meniscus in normal and chymopapain-injected knees of young rabbits. Arthritis Rheum 46: 2495-2503, 2002.

20. Gouze JN, Bordji K, Gulberti S, Terlain B, Netter P, Magdalou J, Fournel-Gigleux S and Ouzzine M: Interleukin-1 beta downregulates the expression of glucuronosyltransferase I, a key enzyme priming glycosaminoglycan biosynthesis: influence of glucosamine on interleukin-1 beta mediated effects in rat chondrocytes. Arthritis Rheum 44: 351-360, 2001.

21. Hua J, Sakamoto K and Nagaoka I: Inhibitory actions of glucosamine, a therapeutic agent for osteoarthritis, on the functions of neutrophils. J Leukoc Biol 71: 632-640, 2002.

22. Ma L, Rudert WA, Harnada J, Wright M, Machen J, Lakomy R, Qian S, Lu L, Robbins PD, Trucco M and Giannoukakis N: Immunosuppressive effects of glucosamine. J Biol Chem 277: 39343-39349, 2002

23. Zhang GX, Yu S, Gran B and Rostami A: Glucosmaine abrogates the acute phase of experimental autoimmune encephalomyelitis by induction of Th2 response. J Immunol 175: 7202-7208, 2005.

24. Hua J, Suguro S, Iwabuchi K, Tsutsumi-Ishii Y, Sakamoto K and Nagaoko I: Glucosmaine, a naturally occurring amino monosaccharide, suppresses the ADP-mediated platelet activation in human. Inflamm Res 53: 680-688, 2004

25. Tsujimoto $\mathrm{M}$, Feinman $\mathrm{R}$ and Vilcek $\mathrm{J}$ : Differential effects of type I IFN and IFN- $\gamma$ on the binding of tumor necrosis factor to receptors in two human cell lines. J Immunol 137: 2272-2276, 1986.

26. Hua J, Sakamoto K, Kikukawa T, Abe C, Kurosawa H and Nagaoka I: Evalution of suppressive actions of glucosamine on the interleukin-1ß-mediated activation of synoviocytes. Inflamm Res 56: 432-438, 2007.

27. Kim YS, Ahn Y, Hong MH, Joo SY, Kim KH, Sohn IS, Park HW, Hong YJ, Kim JH, Kim W, Jeong MH, Cho JG, Park JC and Kong JC: Curcumin attenuates inflammatory responses of TNFalpha-stimulated human endothelial cells. J Cardiovasc Pharmacol 50: 41-49, 2007.

28. Hosokawa Y, Hosokawa I, Ozaki K, Nakae H and Matsuo T Cytokines differentially regulated ICAM-1 and VCAM-1 expression on human gingival fibroblasts. Clin Exp Immunol 146: 540-549, 2006. 
29. Ghosh S, May MJ and Kopp EB: NF-кB and rel proteins: evolutionarily conserved mediators of immune responses. Annu Rev Immunol 16: 225-260, 1998.

30. Ramakers JD, Mensink RP, Schaart G and Plat J: Arachidonic acid but not eicosapentaenoic acid (EPA) and oleic acid activates $\mathrm{NF}-\kappa \mathrm{B}$ and elevates ICAM-1 expression in Caco-2 cells. Lipids 42: 687-698, 2007.

31. Bai A, Guo Y and Lu N: The effect of the cholinergic antiinflammatory pathway on experimental colitis. Scand J Immunol 66: 538-545, 2007.

32. Morohoshi Y, Matsuoka K, Chinen H, Kamada N, Sato T, Hisamatsu T, Okamoto S, Inoue N, Tkahashi H, Ogata H, Iwao Y and Hibi T: Inhibition of neutrophil elastase prevents the development of murine dextran sulfate sodium-induced colitis. J Gastroenterol 41: 318-324, 2006.

33. Qi M and Elion EA: MAP kinase pathways. J Cell Sci 118: 3569-3572, 2005

34. Subramanian S, Rhodes JM, Hart CA, Tam B, Roberts CL, Smith SL, Corkill JE, Winstanley C, Virji M and Campbell BJ: Characterization of epithelial IL-8 response to inflammatory bowel disease mucosal E. coli and its inhibitor by mesalamine. Inflamm Bowel Dis 14: 162-175, 2008.

35. D'Acquisto F, May MJ and Ghosh S: Inhibition of nuclear factor kappa B $(\mathrm{NF}-\kappa \mathrm{B})$ : An emerging theme in anti-inflammatory therapies. Mol Interv 2: 22-34, 2002.

36. Ryo A, Suizu F, Yoshida Y, Perrem K, Liou YC, Wulf G, Rottapel R, Yamaoka S and Lu KP: Regulation of NF- $\mathrm{kB}$ signaling by Pin1-dependent prolyl isomerization and ubiquitinmediated proteolysis of p65/RelA. Mol Cell 12: 1413-1426, 2003.

37. Visekruna A, Joseris T, Seidel D, Kroesen A, Loddenkemper C, Zeitz M, Kaufmann SHE, Schmidt-Ullrich R and Steinhoff U: Proteasome-mediated degradation of IкB $\alpha$ and processing of p105 in Crohn disease and ulcerative colitis. J Clin Invest 116: 3195-3203, 2006.
38. Zarubin $\mathrm{T}$ and Han $\mathrm{J}$ : Activation and signaling of the p38 MAP kinase pathway. Cell Res 15: 11-18, 2005.

39. Hanover JH: Glycan-dependent signaling: $O$-linked Nacetylglucosamine. FASEB J 15: 1865-1876, 2001.

40. Wells L, Vosseller K and Hart GW: Glycosylation of nucleocytoplasmic protein: Signal transduction and O-GlcNAc. Science 291: 2376-2378, 2001.

41. Kudlow JE: Post-translation modification by $O$-GlcNAc: Another way to change protein function. J Cell Biochem 98: 1062-1075, 2006.

42. Jang BC, Sung SH, Park JG, Park JW, Bae JH, Shin DH, Park GY, Han SB and Suh SI: Glucosamine hydrochloride specifically inhibits COX-2 by preventing COX $-2 \mathrm{~N}$-glycosylation and by increasing COX-2 protein turnover in a proteasome-dependent manner. J Biol Chem 282: 27622-27632, 2007.

43. Otto VI, Damoc E, Cueni LN, Schürpf T, Frei R, Ali S, Callewaert N, Moise A, Leary JA, Folkers G and Przybylski M: $\mathrm{N}$-Glycan structures and $\mathrm{N}$-glycosylation sites of mouse soluble intercellular adhesion molecule-1 revealed by MALDI-TOF and FTICR mass spectrometry. Glycobiology 16: 1033-1044, 2006.

44. Chen JT, Liang JB, Chou CL, Chien MW, Shyu RC, Chou PI and Lu DW: Glucosamine sulfate inhibits TNF- $\alpha$ and IFN- $\gamma$ induced production of ICAM-1 in human retinal pigment epithelial cells in vitro. Invest Ophthalmol Vis Sci 47: 664-672, 2006 . 